УДК 504.53:504.054

(C) 2012

Стежко О. В., аспірант *

Житомирський національний агроекологічний університет

\title{
ЕКОЛОГІЧНА ОЦІНКА ВМІСТУ ВАЖКИХ МЕТАЛІВ У ГРУНТІ ЖИТОМИРСЬКОГО РАЙОНУ
}

\section{Рецензент - доктор сільськогосподарських наук Л. Д. Романчук}

\begin{abstract}
Одним із найпоширеніших забруднювачів трунтового покриву є важкі метали, щзо надходять до трунту в результаті дї антропогених факторів, одним із яких є діяльність людини. На землях сільськогосподарського призначення, щзо знаходяться в приватній власності, вирощується понад $60 \%$ рослинницької продукиії, тому вивчення вмісту важких металів на цих територіях є актуальним питанням. У даній роботі представлені результати досліджень вмісту важких металів в орному шарі трунту, відібраного з особистих селянських господарств с. Волиия Житомирського району.
\end{abstract}

Ключові слова: забруднення, особисті селянські господарства, важкі метали, орний шар, трунт, міграція.

Постановка проблеми. Грунтовий покрив $\epsilon$ одним із головних ресурсів планети. Він не лише володіє властивостями, необхідними для ведення сільського господарства, такими як родючість, але й підтримує стабільність навколишнього середовища в цілому. Виходячи з цього збереження і підвищення родючості грунтів - одне 3 основних задач людства.

На землі сільськогосподарського призначення, в першу чергу, на їх продуктивність постійно впливають негативні процеси як природного, так i антропогенного характеру. 3 часом забруднюючі речовини накопичуються в грунті й викликають його фізичну руйнацію.

Забруднення грунтів важкими металами, особливо на територіях, прилеглих до великих міст, стало актуальним питанням сьогодення.

Аналіз основних досліджень і публікацій, у яких започатковано розв'язання проблеми. Оцінкою впливу забруднення важкими металами на різноманітні грунтові процеси і параметри присвячено цілу низку досліджень [5-8].

Основні поняття про мікроелементи та їх функції було розкрито в працях В. А. Ковди, П. А. Власюка, Г. В. Добровольського, Я. В. Пейве та ін. Особливості накопичення й міграції мікроеле- ментів у грунті і рослині житомирського Полісся розкриті у працях Л. Л. Щетініної, Г. А. Корбута, Т. М. Мисливої та ін. $[1,6,7]$.

Усі ці дослідження присвячені оцінці забруднення грунтів великих міст. Однак поза увагою дослідників залишаються питання забруднення земель особистих підсобних господарств, оскільки в Україні традиційно контроль проводиться тільки за землями сільськогосподарського призначення, що знаходяться в користуванні підприємств різних форм власності. Вирощування овочевих культур в особистих господарствах ведеться без достатніх наукових знань і за відсутності екологічно безпечних технологій. Нині спостерігається довгостроковий і надмірний антропогенний вплив на грунт, а гонитва за урожайністю призводить до різкого порушення природного балансу та погіршення екологічної ситуації, що, в свою чергу, призводить до істотного зменшення продуктивності агроекосистем.

Особисті підсобні господарства населення виробляють понад 60 \% продукції рослинництва, проте майже повністю відсутня інформація про агроекологічний стан присадибних земельних ділянок, рівень їх забруднення небезпечними речовинами. Це, в свою чергу, не дає змоги дати комплексну оцінку забруднення продуктів харчування, зокрема овочів, вирощених на цих грунтах.

Мета та завдання досліджень. Метою наших досліджень була оцінка вмісту важких металів у грунті особистих підсобних господарств населення Житомирського району. Для реалізації поставленої мети передбачалось оцінити ступінь забрудненості грунтів особистих селянських господарств кадмієм і свинцем.

Матеріали і методи досліджень. Дослідження проводилися в умовах особистих селянських господарств (ОСГ) с. Волиця Житомирського району протягом 2009-2011 років. Відбір зразків грунту проводили на глибині орного шару 0-30 см, через кожні $10 \mathrm{~cm}$.

\footnotetext{
* Керівник-доктор сільськогосподарських наук В. І. Дубовий
} 
СТОРІНКА МОЛОДОГО ВЧЕНОГО

Вміст важких металів у трунтах присадибних ділянок громадян, 2009-2011 рр.

\begin{tabular}{|c|c|c|}
\hline \multirow{2}{*}{ Шар грунту } & \multicolumn{2}{|c|}{ Вміст важких металів, мг/кг } \\
\cline { 2 - 3 } & $\mathrm{Pb}$ & $\mathrm{Cd}$ \\
\hline \multirow{2}{*}{$0-10 \mathrm{cм}$} & $5,66 \pm 0,52^{*}$ & $0,39 \pm 0,03$ \\
& $5,04-6,31$ & $0,37-0,43$ \\
\hline \multirow{2}{*}{$11-20 \mathrm{~cm}$} & $5,80 \pm 0,82$ & $0,44 \pm 0,05$ \\
& $4,65-6,51$ & $0,38-0,5$ \\
\hline \multirow{2}{*}{$21-30 \mathrm{cм}$} & $6,55 \pm 0,42$ & $0,49 \pm 0,02$ \\
\multirow{2}{*}{ ГДК } & $6,15-7,13$ & $0,47-0,52$ \\
\hline \multirow{2}{*}{ с } & 7,0 & 0,7 \\
\hline
\end{tabular}

Примітка: * у чисельнику вказано середній показник вмісту ВМ, а в знаменнику - межі варіювання min ma max значення вмісту ВM.

Грунт характеризувався наступними агрохімічними показниками: гумус $-3,5 \%, \mathrm{pH}-6,7$, азот лужногідролізований - 147,31 мг/кг, гідролітична кислотність - 0,95 ммоль/кг, сума поглинутих основ - 24,44 мг-екв/кг, вміст фосфору - 433,33 мг/кг. Вміст свинцю та кадмію (рухомі форми) в грунті визначали методом атомно-абсорбційної спектрофотометрії.

Предметом досліджень були важкі метали та орний шар грунту.

Об'єктом досліджень стала динаміка вмісту важких металів у 0-30 см шарі грунту.

Результати досліджень. Результати досліджень на вміст важких металів грунту 3 присадибних ділянок громадян с. Волиця проаналізовано й систематизовано у таблиці.

У ході проведених досліджень встановлено, що в 0-10-сантиметровому шарі грунту вміст свинцю варіював у межах 5,4-6,31 мг/кг, тоді як ГДК для цього елемента становить 7,0 мг/кг, що, в свою чергу, означає, що мали місце поодинокі перевищення гранично допустимих концентрацій. У середньому за ОСГ вміст полютанта становив 5,66 мг/кг. Аналізуючи показники вмісту свинцю в шарі грунту 11-20 см, варто відмітити, що його вміст зростав, у середньому, на 0,15 мг/кг порівняно 3 шаром 0-10 см. Також було відмічено перевищення вмісту полютанта в деяких зразках грунту; при цьому максимальна його концентрація для цього шару становила 6,51 мг/кг.

У шарі 21-30 см зафіксоване подальше зростання елементу, в середньому на 0,75 мг/кг порівняно з попереднім шаром. Варто відмітити, що подекуди вміст полютанта в зразках грунту, відібраних в особистих селянських господарствах, становив 7,13 мг/кг, що перевищує гранично допустимі норми.

Аналізуючи представлені результати досліджень вмісту кадмію в грунті, бачимо, що його вміст у шарі 0-10 см у середньому становив
0,39 мг/кг, максимальне його значення було зафіксовано на рівні 0,43 мг/кг.

Концентрація полютанта в 11-20 сантиметровому шарі грунту коливалася в межах від 0,38 мг/кг до 0,50 мг/кг. Із представлених результатів досліджень можна сказати, що вміст кадмію в 21-30 см шарі грунту суттєво не зростав, а його концентрація коливалася в межах від 0,47 мг/кг до 0,52 мг/кг. Дані показують, що вміст кадмію не мав перевищень гранично допустимих концентрацій.

Аналіз вмісту важких металів в орному горизонті грунтів із особистих селянських господарств дозволив зафіксувати тенденційне підвищення їх концентрації з глибиною в межах досліджуваного шару, що пов'язано з особливостями міграції зазначених полютантів.

Висновки. В останні десятиріччя спостерігається перебудова грунтових екосистем у бік регресивного розвитку практично по всій території області під впливом багатьох забруднюючих факторів, одним із яких є важкі метали.

Отримані результати дають змогу зробити висновок, що спостерігається тенденція до зростання вмісту важких металів кожні 10 сантиметрів грунту в межах орного шару; це було характерно як для кадмію, так і для свинцю. Враховуючи те, що основна маса коренів сільськогосподарських рослин розміщена в шарі $0-30 \mathrm{~cm}, \mathrm{i}$ саме 3 нього овочеві культури використовують максимально поживні елементи, дає змогу припустити, що овочева продукція може містити надлишок ВМ, що, в свою чергу, унеможливлює отримання екологічно безпечних продукції овочівництва.

У ході опитувань населення встановлено, що жоден житель не має чіткої системи внесення добрив залежно від потреб культури, що може спричинити подальшу акумуляцію полютантів у грунті. 


\section{БІБЛІОГРАФІЯ}

1. Власюк П. А. Биологические элементы жизнедеятельности растений / П. А. Власюк. - К. : Наукова думка, 1969. - $516 \mathrm{c.}$

2. Добровольский Г. В. Функции почв в биосфере и экосистемах (экологическое значение почв) / Г. В. Добровольский, Е. Д. Никитин. - М. : Наука, 1990. - $261 \mathrm{c.}$

3. Лісовал А. П. Система застосування добрив: підручник / А. П. Лісовал, В. М. Макаренко, С. М. Кравченко. - К. : Вища шк., 2002. - 317 с.

4. Минеев В. Биологическое земледелие и минеральное удобрения / В. Минеев, Б. Довбиш, Т. Мазур. - М. : Колос, 1993. - 416 с.

5. Мислива T. М. Важкі метали в лісоаграрних ландшафтах Житомирського Полісся / Т. М. Ми- слива, В. А. Трембіцький, Л. Л. Довбиш // Агрохімія і грунтознавство. - 2006. - Спец. вип. C. 260-263.

6. Мислива T. М. Важкі метали в урбоедафатопах і фітоценозах та території м. Житомира / Т. М. Мислива, Л. О. Онопрієнко // Вісник ХНАУ. 2009. - №2. - C. 134-142.

7. Надточій П. П. Екологія грунту та його забруднення / П. П. Надточій, Ф. В. Вольвач, В. Г. Гермашенко. - К. : Аграрна наука, 1997. $286 \mathrm{c}$.

8. Надточій П. П. Екологія грунту: монографія / П. П. Надточій, Т. М. Мислива, Ф. В. Вольвач. Житомир: Вид-во «ПП Рута », 2010. - 473 с. 